JERZY FLAGA - LUBLIN

\title{
PONOWNE SPOJRZENIE NA NAJNOWSZĄ HISTORIOGRAFIE BERNARDYŃSKĄ
}

[Recenzja]: Jan z Komorowa, Kronika Zakonu Braci Mniejszych Obserwantów (1209-1536), przettumaczyt O. Kazimierz Żuchowski OFM, Wydawnictwo Calvarianum, Kalwaria Zebrzydowska 2014, ss. 405; ISBN 978-83-6344011-4;

Kajetan Jan Grudziński OFM, Aleksander Krzysztof Sitnik, Bernardyni w Stużbie Ojczyzny 1453-1953, Calvarianum, Kalwaria Zebrzydowska 2015, ss. 336; ISBN 978-83-63440-12-1;

Romuald Michał Gustaw OFM, Aleksander Krzysztof Sitnik OFM, Klasztor $i$ kościól św. Józefa ss. Bernardynek w Krakowie 1646-2009. Wydawnictwo Calvarianum, Kalwaria Zebrzydowska 2013, ss. 272; ISBN 978-83-6344009-1.

Siedem lat temu zainteresowałem się najnowszą historiografią bernardyńską i przyjrzałem się jej bliżej. Efektem tego było krótkie jej omówienie, które zostało zamieszczone w roczniku naukowym „Kościół w Polsce. Dzieje i kultura”, t. VI, red. Jan Walkusz, Wydawnictwo KUL, Lublin 2007, s. 209-219. Przypomnę, że zaprezentowałem tam trzy następujące publikacje książkowe: Pięćset pięćdziesią lat obecności oo. Bernardynów w Polsce (1453-2003), pod redakcją Wiesław F. Murawca OFM, Damiana A. Muskusa OFM, Wydawnictwo Calvarianum, Kalwaria Zebrzydowska 2006, ss. 740, ISBN 83-89432-47-1; O. Aleksander Krzysztof Sitnik OFM, Bernardyni lwowscy. Historia klasztoru i kościoła pod wezwaniem świętych Bernardyna ze Sieny i Andrzeja Apostoła we Lwowie (14601785), Wydawnictwo Calvarianum, Kalwaria Zebrzydowska 2006, ss. 503, ISBN 83-89432-44-7; Radecznica. Ośrodek życia religijnego i społeczno-kulturalnego, red. Roman Jusiak OFM, Wydawnictwo Calvarianum, Kalwaria Zebrzydowska 2006, ss. 226, ISBN 83-89432-48-X. Okazuje się, że badacze tego zakonu nie przestali interesować się swoją historią. W ostatnim czasie ukazały się trzy nowe publikacje poświęcone zakonowi. Przy tym należy zauważyć, że ich badania idą dwutorowo: z jednej strony dążą do poszerzenia bazy źródłowej, z drugiej groma- 
dzą fakty, które służą pogłębianiu dotychczasowej wiedzy o zakonie. Wykorzystują w tym celu nawet prace już wcześniej wydane, które uzupełniają i ponownie publikują jako drugie wydanie. Na pewno wpływ na rozwój historiografii zakonu mają osobiste zainteresowania i wewnętrzny imperatyw poznawania własnej historii przez poszczególnych autorów, kapłanów tego zakonu. Nie są to bowiem prace pisane na polecenie przełożonych. Tematy ich są zgodne z umiejętnościami nabytymi przez autorów na studiach. Jeden jest $\mathrm{z}$ wykształcenia klasykiem, drugi - historykiem. Nie bez znaczenia - jak się wydaje - był też fakt, że zakon, w tym wypadku konkretna prowincja, posiada własne wydawnictwo. To nie tylko ułatwia, lecz także, jak wolno przypuszczać, zachęca do studiowania i zapoznawania się z własnymi dziejami oraz utrwalania ich w świadomości całej społeczności zakonnej, zwłaszcza wśród adeptów, którzy wstąpili do zakonu i rozpoczynają życie zakonne, które nasycone powinno być wiedzą o własnej przeszłości.

Tłumaczenie Kroniki Zakonu autorstwa Jana z Komorowa K. Żuchowski OFM rozpoczął już wcześniej ${ }^{1}$. Pierwszymi były teksty dotyczące Jana z Dukli i Szymona z Lipnicy. Następne teksty zamieścił w trzech kolejnych numerach „Przeglądu Kalwaryjskiego”: 11/12, 13, 14, wydawanego przez Wyższe Seminarium Duchowne OO. Bernardynów i Oddział Polskiego Towarzystwa Teologicznego w Kalwarii Zebrzydowskiej. Ostatecznie zebrał je ponownie i opublikował w samodzielnej pozycji książkowej, wykorzystując w tym celu wspomniane wydawnictwo Calvarianum. Nie zmienia to wprawdzie merytorycznej wartości wcześniej opublikowanych tekstów w „Przeglądzie Kalwaryjskim”, ale dzięki temu historycy będą mieli ułatwiony dostęp do tego cennego źródła, mając równocześnie - co jest szczególnie pożądane - ogląd jego całości. Należy zauważyć, że dotychczasowi badacze, którzy wcześniej interesowali się Kronika i wypowiadali się na jej temat, utrzymują, że jest to cenne źródło historyczne, szczególnie w odniesieniu do zagadnień zakonnych. Pod koniec XIX wieku dwaj uczeni: Ksawery Liske i Antoni Lorkiewicz tak pisali na jej temat:

Jest prawie wyłącznym źródłem do historii zakonu franciszkanów obserwantów, tym ważniejszym, że jedynym do historii Bernardynów w Polsce ... Zakony, a w pierwszym rzędzie zakon franciszkański, liczący w swym gronie często członków znakomitych rodów, przy religijnym nastroju całego społeczeństwa, nieraz wywierały potężny wpływ na stosunki społeczne, na politykę panujących, biorąc nawet żywy udział w religijno-politycznych wydarzeniach, które nawiedzały współczesne społeczeństwo².

Również współcześni historycy, nie tylko zakonni widzą w Kronice wartościowe źródło. Salezy Bogumił Tomczak OFM i Jacek Wiesiołowski piszą:

\footnotetext{
${ }^{1}$ Interesujące są także koleje życia o. Jana z Komorowa OFM, lecz relacjonowanie ich nie mieści się w ramach obecnych uwag. Tym niemniej warto przywołać jeden fakt, mianowicie ten, że w 1521 roku, w drugim roku swego prowincjalstwa, w czasie wizytacji klasztoru lwowskiego dokonał on elewacji ciała Jana z Dukli, którego postać w naszych czasach została przybliżona, w roku 1997 papież Jan Paweł II kanonizował Go, a parlament polski ogłosił patronem roku 2013.

${ }^{2}$ Monumenta Poloniae Historica, Lwów 1888, t. 5, s. 53 (cyt. za: Jan z Komorowa, Kronika Zakonu, s. 13).
} 
Jako historyk Komorowski jest niesłusznie niedoceniany przez badaczy historii literatury polskiej. Choć wieloletnie uzupełnianie kroniki naruszyło nieco jej konstrukcję, jest to tekst bardziej żywy od współczesnej mu kroniki rektora krakowskiego Macieja z Miechowa czy prałata Bernarda Wapowskiego. W ogóle polska historiografia zakonna, której Komorowski jest pierwszym wybitnym przedstawicielem, pozostaje wciąż jeszcze niezauważona jako rodzaj literacki i typ dzieła historycznego ${ }^{3}$.

Natomiast o samym Komorowskim o. Salezy Tomczyk pisze co następuje:

Złotymi zgłoskami w kronikarstwie bernardyńskim zapisał się Jan z Komorowa. Jego przygoda z kroniką zaczęła się w 1506 roku, kiedy prowincjał Łukasz z Rydzyny w trosce o utrzymanie wśród swoich podwładnych, zwłaszcza młodych zakonników, świadomości historycznej, a także o ukazanie wzorców do naśladowania - polecił mu napisanie dziejów zakonu i prowincji ${ }^{4}$.

Mając na uwadze powyższe opinie, postanowiłem przypomnieć jej polską treść w kontekście najnowszej historiografii bernardyńskiej. Jest to o tyle ważne, że Kronika Jana z Komorowa jest oparta na dobrej podstawie źródłowej. Wiadomo, pisze o tym także o. Kazimierz, że korzystał on z pism i licznych życiorysów św. Franciszka oraz różnych kronik zakonnych (s. 13). Potwierdzają to także inni autorzy, którzy utrzymują, że interesował się on dostępnymi mu źródłami, a niekiedy znał je nawet $\mathrm{z}$ autopsji ${ }^{5}$.

Przystępując do omówienia treści Kroniki należy zauważyć, że nie jest ona ani jedynym, ani pierwszym dziełem o. Jana z Komorowa. Tłumacz K. Żuchowski, wspomina, ze że na polecenie wikariusza prowincjalnego Łukasza z Rydzyny (1503-1506; 1509-1511) J. z Komorowa przygotował zbiór kazań do zakonników zatytułowany Sermones de Regula et Constitutionibus ordinis. Dzieło powstało prawdopodobnie w latach 1503-1506, a było uzupełniane do 1510 roku. Niestety nigdy nie było drukowane i ostatecznie zaginęło. Bernardyński kronikarz jest także autorem traktatu teologiczno-scholastycznego Introductio in doctrinam Doctoris subtilis, który prawdopodobnie służył jako podręcznik i w krótkim czasie doczekał się czterech wydań. Natomiast pierwszą pracą historyczną był Tractatus cronice Fratrum Minorum a tempore ConstanciensisConsilii et specialiter de Provincia Poloniae. Rękopis tej kroniki nosi nazwę Rękopisu Krasińskich. Komorowski pisał ją na polecenie wspomnianego już wikariusza prowincjalnego o. Łukasza z Rydzyny, a mogła powstać około 1512 roku. Kronika będąca najważniejszym i najobszerniejszym dziełem o. Jana Komorowskiego została napisana w ostatnich latach jego życia, gdy nie pełnił już żadnych obowiązków w prowincji. Mieszkał wówczas w konwencie krakowskim, gdzie oddawał się wyłącznie pracy pisarskiej. Właśnie na Stradomiu powstał rękopis kroniki, nazywany Rękopisem Czartoryskich. Na marginesach rękopisu dopisywał różne uwagi i wyjaśnienia. Równolegle z oryginałem przygotowywał kopię rękopisu, nazwaną później Rękopisem Jagiellońskim. Jak pisze o. Kazimierz oba te dokumenty, tzn.

${ }^{3}$ Kroniki Bernardynów poznańskich, oprac. S.B. Tomczak, J. Wiesiołowski, Poznań 2002, s.2 (cyt. za: Jan z Komorowa, Kronika Zakonu, s. 2).

${ }^{4}$ Tamże, s. XIV.

${ }^{5}$ Por. R.M. Gustaw OFM, A. K. Sitnik OFM, Klasztor i kościót św. Józefa ...., s. 6. 
oryginał i jego kopia, nie różnią się między sobą co do treści. Kopia nie stanowi jednak dokładnego odwzorowania pierwotnej wersji. Kronika, której przekład otrzymaliśmy, zaczyna się od słów: Incipit breve memoriale Ordinis Fratrum Minorum ... Zaczyna się krótka kronika Zakonu Braci Mniejszych. Na kartach Kroniki - kontynuuje thumacz - autor przedstawia chronologicznie dzieje swojego zakonu, śledzi przede wszystkim jego początki, wymienia generałów i wikariuszy obserwanckich, omawia herezje i sekty, które w tym czasie powstały, ukazuje rozprzężenie w zakonie i podejmowane próby przywrócenia karności oraz rozwój ruchów obserwanckich. Uwzględnia także ogólne dzieje zakonu. Szczególnie szeroko omawia historię bernardynów w Polsce. Jan z Komorowa rozpoczynając historię zakonu od postaci jego założyciela, tzn. św. Franciszka, doprowadza ją do 1535 roku. W następnym roku umiera. W dalszej kolejności pisze:

Kronika Jana z Komorowa napisana jest językiem żywym, barwnym i obrazowym. Wiele stron opisujących wojny z Tatarami i Kozakami, uczty panów, niezwykłe cuda, dysputy z diabłami, czyta się jak wspaniałe opowieści. Czasem jednak język Jana Komorowskiego bywa niepoprawny, zawiły, niewłaściwie buduje zdania, często zdarzają się powtórzenia. Nie zawsze łatwy do thumaczenia (s. 14).

K. Żuchowski OFM tłumacząc Kronike podzielił jej tekst na trzy części w ujęciu chronologicznym. Część pierwsza obejmuje lata 1209-1453, czyli okres od początku istnienia zakonu do chwili przybycia św. Jana Kapistrana do Polski (s.17-131). Przedstawione są tutaj dzieje różnych ruchów obserwanckich i powstawanie $w$ ich ramach nowych struktur oraz wyjątkowo trudna kwestia franciszkańskiego ubóstwa w tym okresie. Trudno przywoływać tutaj w dosłownym brzmieniu opisy tych faktów i wydarzeń, gdyż równałoby się to z powtórzeniem Kroniki. Aby jednak dać wyobrażenie o jej treści spróbuję zasygnalizować jej zawartość poprzez wybrane przykłady. Otóż zawiera ona szczegółowy opis 204 przeróżnych kwestii, którymi żył w tym czasie zakon. Jedne z tych kwestii są opisane bardzo krótko, dwom lub trzema zdaniami, inne bardziej obszernie, nawet po kilka stronic. Zależało to od ważności omawianych kwestii, przy czym zawsze zachowany jest porządek chronologiczny. Ilustrację pierwszych stanowią na przykład takie kwestie jak: ustanowienie zakonu św. Klary, sobór powszechny na Lateranie, spotkanie Franciszka i Dominika w Rzymie, śmierć [brata] Eliasza, męczeństwo czterech braci [w 1322 r.], czy otrzymanie przez obserwantów prawa przyjmowania do zakonu. Oczywiście nie są to wszystkie kwestie, jedynie wybrane przykłady. Obszernie opisane są na przykład takie fakty jak: kanonizacja świętego Franciszka i przeniesienie jego ciała (s. 41-42), spór braci z Eliaszem (s. 44-46), spór w Paryżu między duchowieństwem świeckim a zakonami żebrzącymi (s. 54-56), osiemnasty generał zakonu brat Gerard Eudes (Odon) (s. 75-78), Bóg troszczy się o prześladowanych (s. 78-80), pierwsza bulla dana obserwantom (s. 94-96), bracia z Węgier w Austrii (s. 126-128). czy wreszcie kwestia: spirytualni ośmieszają błogosławionego Jana Kapistrana (s. 130-131). Należy wyjaśnić, że przywołane teksty nie były dobierane według określonego z góry klucza, pod uwagę brałem wyłącznie ich długość. Podobnie jak przy tekstach krótkich, nie są to wszystkie dłuższe opisy faktów, wyłącznie wybrane przykłady, istnieje szereg 
innych kwestii opisanych, mniej lub bardziej, obszernie. Należy też dodać, że oba rodzaje tekstów są bogato zaopatrzone w przypisy. Wystarczy powiedzieć, że cała część pierwsza posiada aż 190 przypisów, niekiedy bardzo obszernych, no i oczywiście też merytorycznych.

W części drugiej obejmującej lata 1453-1517 autor relacjonuje przybycie św. Jana Kapistrana do Krakowa oraz przebieg rozwoju i działalności zakonu w pierwszych sześćdziesięciu latach jego istnienia w Polsce (s. 135-315). Niezależnie od tego, że część ta obejmuje raczej krótki okres, tłumacz wyodrębnił w niej dwa podokresy: pierwszy trwający od 1453 do 1467 r. i drugi zamknięty latami 1467-1517. Wiadomości zamieszczone w tej części zostały zaprezentowane w podobny sposób jak w części pierwszej, tzn. szczegółowo wyróżniono poszczególne kwestie, którym nadano odpowiednie tytuły. $Z$ zestawu tych wiadomości dowiadujemy się, że w latach 1453-1467 polscy zakonnicy zależeli od wikariusza prowincji austro-czesko-polskiej. Był to równocześnie czas, w którym zakładano bardzo liczne klasztory: prawie co roku powstawał nowy konwent. W latach 1467-1517 zakon w Polsce stanowił już własną wikarię kierowaną przez wikariusza prowincjonalnego zależnego od wikariusza generalnego obserwantów przedalpejskich. Przedstawiona jest także działalność wybitnych i świętych bernardynów tego okresu oraz ich działalność duszpasterska: głoszenie kazań, spowiadanie, wprowadzanie do nabożeństw pieśni $\mathrm{w}$ języku polskim, tworzonych przez własnych poetów oraz zakładanie bractw. Ponadto znajdują się tam wiadomości o wędrówkach zakonników do Ziemi Świętej, do Rzymu, do Asyżu, na kapituły generalne i prowincjonalne. Wszystko to podawane jest w kontekście historii całego zakonu.

W części trzeciej zatytułowanej: Zależność obserwantów od własnego generała (1517-1536) kronikarz przedstawia krótki okres dziejów prowincji bernardyńskiej od formalnego jej powstania w 1517 r. do śmierci o. Jana Kapistrana w 1536 roku (s. 319-376). W ramach tych dziejów omawia bardzo szeroko przebieg kapituły generalnej w Rzymie w 1517 r., w której osobiście uczestniczył. Rysuje także oddzielenie na kapitule gałęzi zakonnej obserwantów od konwentualnych oraz związane z tym niesnaski. W dalszej części omawia podział polskiej prowincji obserwantów na kustodie, tworzenie nowych prowincji, trudności w prowincji litewskiej i wreszcie działalność poszczególnych prowincjałów. Podobnie jak w obu poprzednich częściach, również w obecnej są paragrafy dłuższe i bardzo krótkie. Na koniec należy zaznaczyć, że w przypadku wszystkich części odnosi się wrażenie, iż objętość tekstów nie zależała od ważności treści, a raczej od tego, jakimi kronikarz dysponował informacjami. Jako przykład można podać tekst z części trzeciej pt. spór i niepokoje w zakonie z 1526 roku dotyczące dosłownego zachowania Reguły przez niektórych zakonników, liczy on 7,5 wiersza (s. 372), natomiast kwestia zatytułowana: Protektor zakonu Andrzej de Valle przeciwko braciom obejmuje 2,5 stronicy (s. 373-375). Czy faktycznie wpływ na to miał stan źródeł, trudno jednoznacznie rozstrzygnąć.

Podsumowując należy stwierdzić, że Jan z Komorowa swoją Kronika przekazał nam dużą część historii zakonu, kiedy zapuszczał swoje korzenie na ziemiach polskich. 
Kolejna książka, jaką pragnę tu przywołać, podwójnego autorstwa: Kajetan Jan Grudziński OFM, Aleksander Krzysztof Sitnik OFM, Bernardyni w stużbie Ojczyzny 1453-1953, Calvarianum, Kalwaria Zebrzydowska 2015, która wydawniczo biegnie równo z kalendarzem, jest typowym opracowaniem historycznym. Zanim przejdę do prezentacji jej treści, na wstępie należy zaznaczyć dwa szczegóły: pierwszy, że - jak wskazuje dedykacja - jest ona poświęcona pięćsetnej rocznicy obecności bernardynów w Polsce (1453-1953) i drugi - nadanie jej specjalnej konstrukcji, która sprowadza się do tego, że bezpośrednio po przedmowie autorstwa o. Rolanda Prejsa OFMCap. zamieszczone są: riassunto, bibliografia i wykaz skrótów, a dopiero po nich - wstęp. W tym miejscu można również przywołać ocenę pracy, jaką jej wystawił o. R. Prejs w swojej Przedmowie. Napisał on tam następujące słowa:

Kompetencje obu Autorów są rękojmią, że dostajemy do ręki rzecz napisaną ze znawstwem zagadnienia, relacjonującą fakty i przedstawiającą je we właściwym świetle (s. 9).

Właściwą pracę tworzą: wstęp, 17 rozdziałów merytorycznych i zakończenie. Całość zamykają noty o autorach oraz indeks osób i miejscowości. Liczba rozdziałów pokazuje, że jest to praca bardzo bogata merytorycznie. Nawet przy niezbyt rozbudowanych rozdziałach, suma ich liczb jest zaskakująco duża. Od strony merytorycznej układ pracy nie jest - można powiedzieć - w pełni konsekwentny. Zasadniczo jest on chronologiczny, jednakże w pewnych okresach na pierwszy plan wysuwane są problemy, które zakłócają chronologię. Zakłócenie to jest jednak pozorne, gdyż czynią to nie tyle zagadnienia, co tytuły poszczególnych rozdziałów. Odnosi się to zwłaszcza do sześciu pierwszych rozdziałów dotyczących epoki średniowiecza. A oto ich tytuły: Zastugi bernardynów dla ojczystej mowy (roz. I), Troska bernardynów o zabezpieczenie wschodnich rubieży Rzeczypospolitej (II), Bernardyńskie klasztory ostoja polskości (III), Klasztory bernardyńskie w obronie ojczyzny (IV), Bernardyńskie duszpasterstwo wojskowe (V), Bernardyńskie szkolnictwo w latach niewoli (VI). W powyższym stwierdzeniu nie należy dopatrywać się zarzutu, ile raczej chęci ze strony autorów bernardyńskich, pokazania roli pełnionej przez zakon w danym czasie, co jest raczej z korzyścią dla pracy. Już przywołane tytuły pokazują, w których dziedzinach życia społecznego, zakon odciskał swoje piętno. Kontynuację tego odnajdujemy w następnych rozdziałach. Oczywiście działalność ta zmieniała się z biegiem czasu wraz z pojawianiem się nowych wydarzeń historycznych. Charakterystyczne było w niej to, że zawsze była ona ściśle związana z historią kraju i narodu. Nie przytaczając dosłownego brzmienia poszczególnych tytułów rozdziałów, generalnie należy powtórzyć, że działalność tą cechował duży patriotyzm wyrażany w różnej formie, od manifestacji patriotycznych poczynając do czynnego udziału w powstaniach narodowych oraz zaangażowanie społeczne. Przejawy te dawały znać o sobie przez wszystkie stulecia epoki nowożytnej do czasów współczesnych włącznie. Nie było im obce także duszpasterstwo wśród Polaków na obczyźnie w czasach

${ }^{6} \mathrm{O}$ rocznicy pisałem przy okazji poprzednio omówionych prac, wśród który była praca stanowiąca pokłosie konferencji zorganizowanej z okazji owej rocznicy (por. s. 1 obecnego tekstu). 
niewoli narodowej. Rzeczywiście, była to prawdziwa służba w Ojczyźnie i dla Ojczyzny. Bardzo dobrze, że taka książka się pojawiła. Powiększa ona stan liczbowy historiografii zakonu, ale przede wszystkim poszerza naszą wiedzę o zakonie bezpośrednio i pośrednio o dziejach ojczystych. To każe nam zgodzić się w całej rozciągłości ze wspomnianą na początku pozytywną recenzją o niej wyrażoną przez o. Rolanda Prejsa.

Jak wspomniałem na początku trzecia publikacja (Klasztor i kościót św. Józefa ss. Bernardynek w Krakowie 1646-2009) nie jest w pełni nową, stanowi drugie wydanie pracy o tym samym tytule wydanej w 1947 roku autorstwa o. Romualda Michała Gustawa $\mathrm{OFM}^{7}$. Ówczesne wydanie pracy było związane z jubileuszem 300-lecie istnienia klasztoru św. Józefa. Wydając ponownie pracę uzupełniono ja o okres dziejów klasztoru od roku 1946 do dziś. Dokonał tego znany nam z poprzedniej publikacji historyk, Aleksander K. Sitnik OFM, który dodał rozdział IX: Bernardynki krakowskie w latach 1939-2009. On też, jak odnotowano w przedmowie do II wydania, przygotował całość pracy do druku . Obecnym wydaniem siostry bernardynki pragnęly upamiętnić jubileusz 550-lecia swego powstania. Widzimy jak jubileusze zakonne przyczyniły się do powstawania dzieł historycznych. To bynajmniej nie oznacza, że nie są to prace wartościowe, wprost przeciwnie pisali je zawodowi historycy i znawcy problematyki, związani też duszpastersko (kapelaństwo) z siostrami bernardynkami, a więc znający ducha zakonu. W związku z powyższym uzasadnione wydaje się być przytoczenie słów przed analizą treści pracy, jakie napisano na temat zakonu sióstr bernardynek w cytowanej już przedmowie. Czytamy tam:

Siostry bernardynki należą niewątpliwie do franciszkańskiego nurtu duchowego i obchodziły razem z jubileuszem braci swój własny jubileusz 550-lecia powstania. Podejmując twórczą jubileuszową refleksję, pragnęły na nowo odkrywać łaskę swojego charyzmatycznego początku, by współcześnie jeszcze jaśniej określić swoją tożsamość oraz miejsce i rolę w Kościele i rodzinie franciszkańskiej. Jako formalny początek nowej formacji zakonnej należy przyjąć fundację klasztoru św. Agnieszki na Stradomiu dla istniejącej już wspólnoty sióstr. Klasztor św. Agnieszki powstał w 1459 roku z fundacji Hińczy z Rogowa, kasztelana sandomierskiego i był usytuowany nad Wisłą przy moście Królewskim (s. 6).

Cała praca jest wyjątkowo szeroko rozbudowana od strony konstrukcyjnej. Oprócz wspomnianych dwóch przedmów zawiera: bibliografię, wstęp poświęcony powstaniu zakonu bernardynek w Polsce, dziewięć rozdziałów merytorycznych, zakończenie, summary, riassunto, zusammenfassung, aneksy, noty o autorach oraz indeksy: osobowy i miejscowości. Treść pracy zawarta jest w dziewięciu rozdziałach merytorycznych. Jest ona ułożona chronologicznie i problemowo. Rozpoczyna ją założenie klasztoru św. Józefa, następnie są informacje o klaszto-

${ }^{7}$ O. Romuald M. Gustaw zmarł w 1976 r. w Lublinie w przeddzień jubileuszu 25-lecia pracy na stanowisku dyrektora Biblioteki KUL.

${ }^{8}$ Wspomnianą przedmowę do II wydania napisał O. Andrzej Pabin OFM, wikariusz prowincji zakonu bernardynów w Polsce. 
rze i jego przełożonych do roku 1788. Potem omówiono przyłączenie klasztoru św. Agnieszki (1788) i św. Kolety (1823) do klasztoru św. Józefa. W trzech dalszych rozdziałach są poddane analizie kolejno: życie w konwikcie, reforma klasztoru w XIX wieku i uposażenie klasztoru. W rozdziale VII i VIII przedstawione są dzieje zabudowań oraz opis kościoła i klasztoru. Rozdział IX jest całkiem nowy - dodany przez A.K. Sitnika OFM - jest on poświęcony dziejom bernardynek w latach 1939-2009.

Jak było już zaznaczone, do pracy dołączony jest aneks. Składa się na niego aż 10 różnych tabel o bardzo zróżnicowanej rozpiętości. Ponieważ uzupełniają one w dużym stopniu pracę, dlatego pozwalam sobie przytoczyć je tutaj: 1 . Spis przełożonych klasztoru św. Józefa; 2 . Siostry, które przybyły na nową fundacje z klasztoru św. Agnieszki; 3. Siostry obłóczone w klasztorze św. Józefa; 4. Siostry, które zostały przeniesione z klasztoru św. Agnieszki do klasztoru św. Józefa w roku 1788; 5. Siostry, które przeniesiono z klasztoru św. Klotyldy do klasztoru św. Józefa w roku 1823; 6. Siostry, które przyjęte zostały do klasztoru św. Józefa z klasztoru ss. Bernardynek w Wieluniu w roku 1880; 7. Spis kapelanów (spowiedników) klasztoru św. Józefa; 8 . Spis osób świeckich pochowanych w grobach kościoła św. Józefa; 9. Przemowa przy wyborze przełożonej wygłaszana przez o. prowincjała w XVIII wieku; 10. Klasztory bernardynek według daty fundacji do dzisiaj istniejące w Polsce.

Rozważania swoje pragnę zamknąć słowami zaczerpniętymi z zakończenia, oddają one bowiem najlepiej treść całej pracy. Napisano w nim:

„Chociaż właściwym zadaniem sióstr klasztoru św. Józefa była doskonałość wewnętrzna, praca cicha, ukryta i nikomu nieznana, to jednak warunki zewnętrzne wymagały nieraz od nich pewnego wkładu w dobro społeczne. Praca zewnętrzna sióstr nie była nigdy jednak pomyślana na szerszą skalę i była traktowana jako coś pobocznego. Nie bez znaczenia było wychowywanie od samego początku przez siostry tego klasztoru młodych dziewcząt. [...] Zasługuje także na wzmiankę działalność charytatywna klasztoru św. Józefa. [...]. Pośrednio także w pewnej mierze konwentowi św. Józefa, jako klasztorowi macierzystemu, należy przypisać istnienie świetnie rozwijających się na początku XX wieku prowincji bernardynek polskich w Ameryce. Wreszcie istnienie klasztoru św. Józefa nie było bez znaczenia dla miasta. Dzięki usilnym staraniom prostych i bardzo słabo uposażonych zakonnic miastu przybyła jeszcze jedna świątynia, którą one, mimo wojen i klęsk, jakie później spadały na miasto potrafiły w pięknym stanie do dziś utrzymać. Patronowi kościoła św. Józefowi, mieszkańcy Krakowa oddawali zawsze szczególna cześć, a bernardynki, szerząc ją uroczystymi nabożeństwami i założeniem bractwa, spotykały się z ogólną sympatią (s. 196). 